Integritas 1.3 (Spring 2013), pp. 1-18.

doi: 10.6017/integritas.v1i3p1

\title{
Welcoming the Religiously Other to a Catholic University
}

\section{Chester Gillis}

From its beginnings, Georgetown College welcomed students of all faiths. Today, that imperative finds roots in the Vatican II document Nostra Aetate and serves the good of interreligious dialogue in a globalized world. Georgetown describes its posture as "centered

pluralism," remaining in the Catholic tradition while engaging in conversation with others. An ongoing challenge is how to remain centered in Catholic tradition and at the same time be truly open to encounter with the religious other.

\section{Introduction}

In the spring of I968, Gerald Campbell, S.J., president of Georgetown University, invited Rabbi Harold White from the University of Michigan to visit Georgetown. Over lunch, Fr. Campbell asked the rabbi to consider coming to Georgetown. Surprised by the invitation, Harold responded that Georgetown did not have many Jewish students, so why would he need a rabbi? ${ }^{\text {I }}$ President Campbell explained that he did not invite the rabbi to teach Jewish students but to teach Catholic students. When asked why, Fr. Campbell responded that Jesus was born a Jew, lived as a Jew, and died as a Jew, and Catholic students need to know the Jewish Jesus. With this explanation, and after traveling back on a beautiful Washington spring day to be greeted by an April I5 blizzard in Ann Arbor, Rabbi White agreed to join Georgetown. He stayed forty-one years as the rabbi in campus ministry and a teacher in the theology department. During those decades, Georgetown sent more students to the rabbinate than did Brandeis University. Rabbi White retired in 2010.

Chester Gillis is dean of Georgetown College, a professor in the Department of Theology, and the director of the Program on the Church and Interreligious Dialogue in the Berkley Center for Religion, Peace, and World Affairs at Georgetown University. Dr. Gillis is an expert on the U.S. Catholic Church, the history of Catholicism, the papacy (including Pope Benedict XVI), interfaith dialogue, and religious pluralism. He is the author of Roman Catholicism in America; Pluralism: A New Paradigm for Theology; A Question of Final Belief; Catholic Faith in America; and the editor of The Political Papacy.

1. At the time, about one percent of students were Jewish. Today, about seven percent are Jewish. 
Before his death in 20I2, Fr. Campbell lived to see his vision of a Catholic university that respects other religious traditions fulfilled. In I999, Georgetown welcomed Imam Yahya Hendi, the first American university to hire a full-time imam on its campus ministry staff. After Rabbi White's retirement, Rabbi Rachel Gartner succeeded him. Today, the campus ministry enjoys the largest staff in the country, with professionals serving Catholics, Protestants, Orthodox, Jews, and Muslims, and complementary student groups for the Bahá'i, Buddhist Meditation Sangha, Hindu, Latter-Day Saints, and Sikh communities.

When asked to participate in the Boston College Roundtable, I was not certain what to expect. When asked to present at the first weekend gathering, I was reluctant until I saw the topic and suggested to the conveners that I would focus on Georgetown University's charism and method of hospitality. Thus, I am addressing this topic through the lens of my experience at Georgetown, which, though not unique among Jesuit colleges and universities, I believe is distinctive.

\section{A Brief History of the Jesuits in America and Georgetown}

That distinctiveness begins with John Carroll, the first American bishop and the founder of Georgetown College in I789. In a period when Catholics were persecuted and under suspicion in the early republic, Catholics in Maryland encountered obstacles from additional taxation to restrictive oaths. However, by and large, they enjoyed greater freedom to practice their religion than did Catholics in other colonies. Their numbers grew, with the greatest concentration in St. Mary's and Charles counties in southern Maryland, swelled in part by immigrants from Ireland. Eventually they spread north to the territory of Pennsylvania, where the Quakers had a policy of freedom of religion.

An internal Church matter-the suppression of the Jesuit order by Pope Clement XIV in I773-could have derailed Catholic development, apart from the political and social pressures from the Protestant majority. Fortunately, twenty-one Jesuits in Maryland and Pennsylvania found a capable leader in John Carroll, who would manage to keep them together and go on to become the first American bishop. He would found a Catholic college in Maryland that he named Georgetown. In a time of prejudice against Catholics and of Protestant hegemony, Carroll declared that his new academy would be open to students of all religious persuasions. In its first ten years of its existence, nearly onefifth of its students were non-Catholics. Today, about fifty percent of its students are non-Catholics. In its early years, the non-Catholics were Protestants. Today, the campus population includes Protestants, Jews, Muslims, Hindus, Buddhists, Latter-Day Saints, and students not affiliated with any religious tradition. This may not be very different from many other contemporary Catholic colleges and universities in the United States. It is, however, different from some- - such as the University of Notre Dame, which has a student body that is more than eighty percent Catholic. ${ }^{2}$

2. See the University of Notre Dame website at http://admissions.nd.edu/hs-counselors/notre-dameby-the-numbers/.
The rationale for outreach to non-Catholics has

deep roots in the Jesuit tradition.

\section{Why Welcome the Religiously Other?}

"Why should a Catholic university welcome the religiously other?" some Catholics may ask. The answer is both obvious and subtle. The obvious part involves demograph ics. The United States, and in particular the nation's capital, constitutes one of the most religiously diverse societies in the world. One cannot (or should not) ignore those who profess a faith different from Catholic Christianity. Georgetown students come from I40 countries and all fifty states. They bring their religion with them. At Georgetown, this experience has its roots in our founder, Archbishop John Carroll, and our founding documents. The College of Georgetown, founded in 1789 , would be open "to students of all religious persuasions." 3

While such openness to the religiously other may have been quite unusual for a Catholic school at that time, the rationale for outreach to non-Catholics has deep roots in the Jesuit tradition. In the sixteenth century, Francis Xavier (I506-1552) traveled to India, Indonesia, and Japan and attempted to reach mainland China. Roberto De Nobili and Constanzo Beschi followed later with journeys to India. Mateo Ricci (I552-16IO) reached China and embarked on a Jesuit mission that found him adopting Chinese cultural habits, including speaking Chinese and dressing in the local Chinese garb. Today's theologies of inculturation owe a deep debt to these pioneers.

These early missionaries wanted to convert the local populations to Christianity. They worked with a theological assumption that salvation required one to be Christian. The well-known but often-misinterpreted phrase of Cyprian (c. 206-258)-extra ecclesiam nulla salus ("outside the church no salvation")—-had largely shaped the form of the Catholic response to other religions until the twentieth century. ${ }^{4}$ The Catholic Church has witnessed periods in its history of both tolerance and intolerance in its understanding of non-Catholics and non-Christians. Cyprian's phrase, strictly interpreted, mean that only those who were visible members of the Church enjoyed the possibility of salvation. Thus, from the early centuries, there was a Catholic provincialism regarding the doctrine of salvation

Vatican II opened the Church to other religions in new ways, theologically. The document "Declaration on the Relationship of the Church to Non-Christian Religions"

3. Robert Emmett Curran, A History of Georgetown University: Volume 1, From Academy to University 1789 1889 (Washington, D.C.: Georgetown UP, 2010), pp. 25-26.

4. For some recent retrievals of this position, see Jerome Theisen, The Ultimate Church and the Promise of Salvation (Collegeville, Minn.: St. John's University Press, 1976) and Gavin D'Costa, "Extra Ecclesiam Nulla Salus Revisited," in Religious Pluralism and Unbelief: Studies Critical and Comparative, edited by lan Hamnett (London: Routledge, 1990). 
(Nostra Aetate), 5 the shortest produced by the participants of the Second Vatican Council, deals with the question that is among the most pressing for the contemporary Church. That is, what is the relationship between the Catholic Church and the major world religions? The document itself does not treat explicitly the intricacies and delicacies of the theological ramifications of an interreligious dialogue. That is not its purpose. Rather, it was designed to stimulate theological thinking, and in that it has succeeded. In a commentary published shortly after the time of the Council, John Oesterreicher correctly observed, "In it [Nostra Aetate], a Council for the first time in history acknowledges the search for the absolute by other men and by whole races and peoples, and honors the truth and holiness in other religions as the work of one living God." 6 This recognition of the positive elements in the world religions connoted a new era in ecumenism. This short document was more a movement to openness than a plan of action. It signaled an openness to dialogue, beyond the world of separated Christian churches, with those who do not recognize Jesus Christ as "the way, the truth and the life" (John I4:6) in any exclusive manner.

The document carefully and gently encouraged Christians to

prudently and lovingly, through dialogue and collaboration with followers of other religions, and in witness of Christian faith and life, acknowledge, preserve, and promote the spiritual and moral goods found among these men, as well as values in their society and culture.?

The world and the United States remain religiously diverse. A Catholic institution of higher learning can ignore this reality, but in so doing, it cannot change it, and its graduates will enter a religiously diverse society

no matter in what area of the country they settle.

This attitude is reflected in other documents of the Council as well, ${ }^{8}$ indicating the seriousness of the participants' attempts to promote respect for dialogue with the other major religions of the world.

Those major religions now commingle on campuses of Catholic colleges and universities. Georgetown represents but one example. Each year Boston College welcomes

5. Nostra Aetate, online at www.vatican.va.

6. Declaration on the Relationship of the Church to Non-Christian Religions, "Introduction and Commentary," trans. by Simon and Erika Young and Helda Graef in Commentary on the Documents of Vatican II, Volume Three, H. Vorgrimler (ed.) (London: Burnes \& Oates, 1969), p. 1.

7 Nostra Aetate 2, trans. Young and Graef.

8. See, for example, Ad Centes 11, 12, 16, 34, 41; Caudium et Spes 3, 23, 58, 92; and Apostolicam Actuositatem 14, all online at http://www.vatican.va/archive/hist_councils/ii_vatican_council/. a religiously diverse class to Chestnut Hill, with seventy percent self-identifying as Catholic. The University of Notre Dame reports eighty-three percent Catholics while Seattle University, a Jesuit school, has thirty-three percent Catholics. Gonzaga University reports more than twenty faiths represented on campus. There are, of course, some colleges and universities, such as the Franciscan University of Steubenville and Ave Maria University, that attract Catholics exclusively and therefore have a different campus climate in relation to issues of religious diversity.

In 1996 the faculty produced a document that described Georgetown's religious identity as "centered pluralism," meaning that Catholicism anchors or centers that identity but that its religious identity as reflected in its students and faculty is pluralistic.

Whatever the percentage of Catholic students on a given campus, the world and the United States remain religiously diverse. A Catholic institution of higher learning can ignore this reality, but in so doing, it cannot change it, and its graduates will enter a religiously diverse society no matter in what area of the country they settle. Welcoming and getting to know the religiously other while in college prepares Catholic students for the world that they will enter upon graduation. I have often told Georgetown students who join the Church while in college through the Rite of Christian Initiation of Adults (RCIA) that they are joining the universal Roman Catholic Church and not only the campus ministry. Georgetown's Dahlgren Chapel offers a variety of liturgies geared toward university students, presided over and preached by Jesuits who are scholars and teach ers. When students graduate, they will be faced with a quite different pastoral and liturgical landscape that will not be targeted to their circumstances. They will hear harangues from the pulpit, be asked regularly for money, experience uninspiring liturgical music from a church organist or choir, and at times be the only twenty-somethings at Mass After all, they joined the Church, not campus ministry. They will, of course, also find vibrant parishes that welcome them and engage their talents. They just may have to look for them and not settle on the local parish because it is nearby.

\section{A Focus on Interreligious Dialogue}

Georgetown, a locus of interreligious dialogue, not only welcomes students and faculty from many religious traditions, it actively encourages them to engage in dialogue with each other. Home to the Berkley Center for Religion, Peace, and World Affairs, the Prince Alwaleed Bin Talal Center for Muslim-Christian Understanding, the Program for Jewish Civilization, and a theology department whose Ph.D. program focuses on religious pluralism, Georgetown enjoys an international reputation for interreligious 
dialogue. In 1996, the faculty produced a document that described Georgetown's religious identity as "centered pluralism," meaning that Catholicism anchors or centers that identity but that its religious identity as reflected in its students and faculty is pluralistic. This underscores to non-Catholics who attend or work at Georgetown that they have a place in the conversation. The core identity of the institution, appropriately, resides in Catholicism.

That Catholic identity, however, while informing the key principles of the university, invites participation in and conversation with the religiously other. How this works in practice varies. Faculty understand the Jesuit charism of cura personalis that attends to the whole person in the context in which he or she abides. They support the desire for our students to be men and women for others. They are also invited to enter into Ignatian spirituality as my wife and I have done. In different years and with different cohorts, each of us participated in the Igth Annotation retreat for an entire year including regular prayer, spiritual direction, and gatherings with fellow retreatants to reflect on Scripture, prayer, and ministry.

This opportunity provides powerful testimonies, strengthens the bonds to the Jesuit mission and the institution, and sometimes produces some surprises. At the final formal meeting of my cohort, one of my colleagues whom I admired for his commitment to spirituality and social justice announced that he would enter the seminary and seek ordination. Incredulous, since I knew that he was married and believed he was a Catholic, I said that he would not be eligible for ordination, to which he responded, "Oh, I am not Catholic, I'm Methodist." No one in our group would have imagined that he was not Catholic since he participated in ways that would lead one to believe he had intimate familiarity with the Jesuit tradition, which indeed he did.

He, of course, represents a significant portion of our faculty who, though not Catholic, understand and support the Jesuit mission. With the decline in the number of Jesuits on campuses, collaboration between lay faculty from all religions (and none) and the mission of the university becomes increasingly critical. I recently saw an article that reported on the significant number of Catholics in the current (II2th) Congress of the United States. The article, written by someone at a Jesuit university, noted that the largest number of Catholic senators and congresspersons were "trained by the Jesuits." To some readers this may conjure up visions of a bygone era when the good Jesuit Fathers in cassocks taught classes and monitored study halls. But we who work in Jesuit institutions know better. It is we who are educating the next generation of politicians in the Jesuit tradition, not Jesuits. Georgetown Law Center, which has educated many in Congress, has one Jesuit—Ladislas Orsy, S.J. —on its faculty and he, although robust and lucid, is ninety-one years old! What the article headline should have said to be more accurate is that Jesuit colleges and universities have educated the most Catholics in Congress. This we can be proud of and take credit for. Quite a few of these legislators who have received this Jesuit education, by the way, are not Catholics. But that goes directly to my point. Jesuit institutions educate leaders from all religions (and none).
In order to do this in the twenty-first century, many Jesuit schools, and Georgetown especially, emphasize interreligious dialogue as they welcome the religiously other on their campuses and in their classrooms. Years ago I observed that this trend would grow underscoring the need for dialogue among the religions:

Just as in the days immediately following Vatican II, when any number of initiatives was launched for dialogue between the Catholic and Protestant traditions of Christianity, so in the final decade of the twentieth century and into the twenty-first century, regional and local inter-faith dialogues must be undertaken in addition to the national and international dialogues already underway. These exchanges and encounters should be under the auspices of both diocesan bodies and individual congregations. They should continue with the initial basic objectives of dismantling caricatures and promoting proper mutual understanding of the traditions involved. Once this goal is achieved, and it is no small accomplish ment, the dialogue may proceed to address mutual concerns and theological questions that arise within and out of the exchange. These mutual concerns may be social, political, or religious. 9

It is clear that such endeavors now dot the American landscape, in dioceses and universities. Interreligious dialogues can also take place on Catholic college campuses Theologically, we have come a long way from the first parliament of the world's religions in Chicago, in I893, when seventy-eight percent of the 194 papers were delivered by Christians and seventy-three percent of the Christian participants were from the United States. The 2004 parliament in Barcelona, Spain, gathered 9,000 participants from seventy-five countries and included 450 programs, lectures, dialogues, workshops, symposia, performances, and exhibits, with 962 presenters representing faiths from around the world. The 2009 Melbourne, Australia, parliament drew 8,900 participants.

Kusumita Pedersen, in an article titled "The Interfaith Movement: An Incomplete Assessment," suggests that the most common motives for engaging in interfaith work are: "(I) to live together harmoniously, mitigate tensions, and resolve conflict; (2) to engage in a 'common task'; and (3) to search for truth and understanding in the context of religious plurality." ${ }^{\text {Io }}$ Interfaith organizations have seen explosive growth in the past quarter-century. A I980 study conducted by the National Council of Churches Committee on Religion and Local Ecumenism reported twenty-four interfaith councils in the United States. By 2006, Diana Eck's Pluralism Project at Harvard had identified over five hundred.

Kate McCarthy, author of the 2007 book Interfaith Encounters in America, explores whether interfaith groups come together to achieve a common goal or if coming together is the goal. She writes:

9. Chester Gillis, Pluralism: A New Paradigm for Theology (Leuven, Belgium: Peeters, 1993), pp. 34-35.

10. Kusumita P. Pedersen, "The Interfaith Movement: An Incomplete Assessment," Journal of Ecumenical Studies 41:1 (2004), pp. 74-94 
The "religious organizations" heading in telephone books across American cities, no longer limited to churches and the occasional synagogue, now include mosques, Hindu temples, Sikh gurdwaras, and Buddhist meditation centers. The religions of these immigrant communities are dramatically restructuring traditional models of "interfaith" efforts, which used to refer to the work of Catholics, Protestants, and Jews trying to better understand each other. Community-based interfaith projects today might involve Hmong elders educating neighbors about their shamanic practices, or Sikhs inviting other local religious groups to help celebrate the opening of a new temple. ${ }^{\text {II }}$

\section{Examples of Dialogue at Georgetown}

Permit me to describe the efforts of a Georgetown organization that promotes interfaith dialogue. I hope that the descriptions of the work of this organization will mirror to some degree the efforts that are taking place on the campuses of Catholic colleges and universities across the country.

The Berkley Center for Religion, Peace, and World Affairs, created in March 2006, explores the intersection of religion with contemporary global challenges: relations among states and societies; global development; democracy and human rights; and culture and identity. Two premises guide the Center's work: that scholarship on religion and its role in world affairs can help to address these challenges effectively; and that the open engagement of religious traditions with one another and with the wider society can promote peace. ${ }^{\text {I2 }}$

\section{Two premises guide the Center's work: that scholarship \\ on religion and its role in world affairs can help to address these challenges effectively; and that the open engagement of religious traditions with one another and with the wider society can promote peace.}

The center sponsors lectures, symposia, and seminars by figures in the academy and the public arena, including Tariq Ramadan, Theodore Cardinal McCarrick, Anthony Appiah, E. J. Dionne, Jim Wallis, Abdolkarim Soroush, Jose Cassanova, John Esposito, Jean Elshtain, Yossi Shain, Robert Wuthnow, Grace Davie, and Rick Warren, to name only some of the notable participants in Berkley Center events in recent years. The center's programs have addressed a wide range of topics, including "AIDS in Africa," "Evangelicals and Foreign Policy," "Martyrdom in Christianity, Islam, and Judaism,"

11. Kate McCarthy, Interfaith Encounters in America (New Brunswick, N.J.: Rutgers, 2007), p. 7

12. Berkley Center website: http://berkleycenter.georgetown.edu/.
"Islam, Catholicism, and the Secular," "Culture, Religion, and Globalization," "Women in Interreligious Dialogue," and "Religion and Migration." The center is part of an effor by Georgetown, led by Georgetown president John DeGioia, to be a global leader in interfaith understanding.

Let me describe in more detail just two of the projects that the center has mounted. The first is titled "Mapping the Role of Faith Communities in Development Policy: The U. S. Case in International Perspective." ${ }^{\text {ז }}$ The report maps the work of faith-inspired organizations that are engaged in international development and relief work: "what and where they are, what general categories may be distinguished, what they do, and what special generic features characterize them." ${ }^{14}$ It presents some of the details of a few organizations to indicate the type of organizations involved and the type of work each does. It distinguishes development-focused on long-term change-and relief that constitutes emergency assistance. The report attempts to if not define, at least describe what constitutes a "faith-based organization." In the light of George W. Bush's creation of a government Office of Faith-Based and Neighborhood Initiatives, which assists faithbased groups to negotiate the federal grant system, this topic has taken on a larger role in American society and internationally. The report expresses concern that "faith-based" will mean, in essence, Christian. It reads, "Given the general predominance of Christianity in the United States, both practitioners and scholars have expressed concern that both on the ground and theoretical and definitional work will be subtly skewed against non-Western religions with less formal structures and different theological frameworks for compassionate action." "15

In 2004, Ronald Sider and Heidi Rolland Unruh produced a typology based on case studies of domestic community-service organizations that separated organizations into six different categories (listed from most to least faith-based): faith-permeated, faith-centered, faith-affiliated, faith-background, faith-secular partnership, and secular. They described categorical archetypes according to eight criteria, some of which included mission statement, board member and staff selection, and financial support. ${ }^{16}$

While Christians likely get the lion's share of grant money, the Berkley Center report highlights the contributions of multiple religions: Catholic (Catholic Relief Services) Mainline Protestant (Church World Service-the relief and development arm of the National Council of Churches), Evangelical (World Vision), Orthodox (International Orthodox Christian Charities), Mormon (various efforts), Jewish (American Jewish Join Distribution Committee), Islamic (One Ummah International), Buddhist (International

13. "Mapping the Role of Faith Communities in Development Policy: The US Case in International Perspective" (Washington, D.C.: Berkley Center for Religion, Peace \& World Affairs, January 1, 2007) http://berkleycenter.georgetown.edu/publications/mapping-the-role-of-faith-communities-in development-policy-the-us-case-in-international-perspective

14. "Mapping," p. 7.

15 "Mapping," p. 9.

16. "Mapping," p. 11 
Network of Engaged Buddhists), Hindu (Ramakrishna Mission), and Baha'i (Baha'i International Community), to name some of the faith-based organizations associated with these sects or religions.

The report cautions that religiously based organizations are not accustomed to conducting formal evaluations ("assessments" being the current term in academia and elsewhere) and are thus less likely to identify and address failures or formally strategize improvements. Another concern is proselytization. Whenever a religious organization has something to offer in terms of goods or services, it must be able to separate its social mission from its religious mission. The report notes the following:

A core principle of humanitarian aid, codified in the Code of Conduct for the International Red Cross and Red Crescent Movement, is that aid will not be used to further a particular political or religious standpoint. In particular, the code states that organizations "will not tie the promise, delivery or distribution of assistance to the embracing or acceptance of a particular political or religious creed." " ${ }^{7}$ Most FBOs subscribe to this idea, but as more FBOs work in the relief and development field and missionary organizations increasingly offer international aid, this principle is being challenged. Sometimes the challenge is overt, as in the case of Baptists delivering food aid with biblical verses in predominantly Muslim Iraq ${ }^{\mathrm{I} 8}$ or Christian aid workers in an earthquake relief camp staging plays about Jesus and hold healing prayer sessions, ${ }^{19}$ but in other cases the line between proselytization and aid organizations with religious affiliation is more subtle, such as a picture of Christ on the wall or prayer before aid workers begin their daily activities. ${ }^{20}$

Religious and interreligious organizations must be mindful that they exist to do good for others and not simply to do good for themselves.

The second project under the auspices of the Berkley Center is one with which I have been directly involved. Annually, the center invites ten students to serve as undergraduate fellows. Under the direction of a faculty member, the students work on a yearlong project that involves multiple religions. One year's project explored interreligious marriage. Interreligious marriages constitute both a demographic inevitability and a mixed blessing. Changing immigration patterns, wider social boundaries, more open religious understandings, and greater social tolerance have led increasing numbers of people to marry outside of their traditional religious communities. Interreligious marriages may present a valuable asset for communication and understanding in our multicultural society. Or, they may contribute to the dissolution of cultural and religious identity.

17. The Code of Conduct for the International Federation of the Red Cross and Red Crescent Societies can be found at http://www.ifrc.org/publicat/conduct/code.asp.

18. Amanda Bower and Sparisim Chosh, "A Faith-Based Initiative," Time 161:16 (April 21, 2003)

19. David Rohde, "Mix of Quake Aid and Preaching Stirs Concern," The New York Times (January 22, 2005).

20. "Mapping the Role of Faith Communities in Development Policy," p. 22.
They may strengthen or weaken the spiritual traits of individuals and couples. They may nourish new forms of spirituality, but at the cost of traditional structures.

This project examined the challenges of interreligious marriage and constructed a theology by which couples can forge a mutually satisfying religious life in an interreligious union. Through background research and a series of structured interviews with couples in interreligious marriages, the fellows' team added to our knowledge in this important area and published their findings in late 2008. The fellows were Protestant, Catholic, Jewish, Hindu, and Muslim. By working together and by interviewing couples in interfaith marriages, these students, I hope, left Georgetown with a deeper appreciation of religious similarity and difference and a sense of hope for the interreligious future they will encounter. The project consultant, Erika Seamon, a Ph.D. student in theology, later produced her own book on the subject that explores the spirituality and religious identity of interfaith couples. ${ }^{21}$

\section{Criticism and Controversy}

Sometimes in welcoming the religiously other, a Catholic university can invite criticism and controversy. Not everyone welcomes religious diversity—or, more accurately, the consequences of taking religious diversity seriously—at a Catholic university. Such was the case at Georgetown in the I990s, when alumni learned that not all of the classrooms

Not everyone welcomes religious diversity at a Catholic university.

displayed a crucifix, a fixture for previous generations. Before Vatican II, students would face the crucifix in the front of the room and say a prayer before class. Catholic students were also required to attend daily Mass and retreats.

In I996, Elizabeth Fiore, then a first-year student in the college (now Sr. Elizabeth Fiore, V.H.M.), noted that there was no crucifix in a classroom in which she wanted to pray. In the years after Vatican II, the university had not included crucifixes in newly constructed buildings. Fiore organized the Committee for Crucifixes in the Classroom and during the next year the group unsuccessfully worked to petition the university to place crosses in every classroom on campus. ${ }^{22}$ With the faculty becoming as religiously diverse as the student body, some faculty members expressed discomfort at having crucifixes in the classrooms. The university appointed a task force to study the matter and announced

21. Erika B. Seamon, Interfaith Marriage in America: The Transformation of Religion and Christianity (New York: Palgrave Macmillan, 2012).

22. For a recent account of the crucifix controversy, see Laura Engshuber's "At a Crossroads: Georgetown's Evolving Catholic Identity," in The Hoya-The Guide: The Weekly Magazine for Life on the Hilltop, http://www.thehoya.com/the-guide/at-a-crossroads-1.2833098\#.USDxcHAmauk, published March 29, 2012, and updated March 31, 2012 
a new policy in I998, which resulted in aesthetically attractive donated crucifixes being placed in classrooms accompanied by plaques explaining their importance and history. The Intercultural Center building stood as the exception, with symbols of various religions in keeping with the intention of the structure and honoring the many religious identities present on campus. The Torah, Qu'ran, and scriptures or symbols significant to other religions are displayed near the main elevators on each floor.

The website for Georgetown's Office of Mission and Ministry reads: "As a Catholic and Jesuit university, we respect the wide variety of religious and humanist perspectives of our colleagues. We strive to represent a 'centered pluralism' in our offerings and respectfully engage the particular traditions represented in our community." ${ }^{23}$ This echoes the "centered pluralism" document created by the faculty in the I990s. The faculty acknowledged both the centrality of Catholicism to the university and the fact of religious diversity among the staff, administrators, faculty, and students. Georgetown remains centered in Catholicism but recognizes the pluralism of religions that its community embraces. Therefore, without surrendering its Catholic identity, the university seeks to recognize and respect the religiously other. This balance, of course, is not always easy to achieve. Sometimes those who are deeply invested in the institution's Catholic identity can become provincial in their protectionism. Sometimes, those who favor enfranchising persons from all traditions and none, want to do so at the cost of core Catholic beliefs and practices. But this represents the tensions present in a pluralistic society, tensions experienced by Americans in the political and public policy arena on hotly contested issues such as abortion, gay marriage, and immigration reform.

I vividly recall a Jewish student complaining to me that the university did not designate the Jewish high holy days as holidays in the calendar. He was obviously religious and just as obviously had come to Georgetown from a Jewish day school without much thought about matriculating into a Catholic university. I politely informed him that Georgetown is a Catholic university that respects all religious practice and excused him from class for the Jewish high holy days. I also reminded him that for the first time in his academic career, he would enjoy some spring holidays on Holy Thursday, Good Friday, and Easter Monday when the university would be closed to observe the Catholic "high holy days." He understood and appeared pleased.

\section{This Charism in the Curriculum}

Often those charged with maintaining the religious identity of a Catholic university (for example, the president, the board of directors, the Office of Mission and Ministry, Campus Ministry) as well as others who have a stake in that identity (for example, the local bishop, alumni, the campus Jesuit community) want this identity to manifest itself in the curriculum as well as in extracurricular activities. Thus, Campus Ministry provides liturgies, retreats, and spiritual direction for students. However, students are not obligated to engage Campus Ministry. They do so on a voluntary basis. Recognizing the

23. http://missionandministry.georgetown.edu/. voluntary nature of this association, many stakeholders want to find ways to touch all students, and the vehicle for this rests with the curriculum. Responsibility for the cur riculum, however, resides in the hands of the faculty, many of whom may be more concerned with their discipline than with the Catholic identity of the institution. In Jesuit universities and colleges, certain academic programs and disciplines lend themselves to this Catholic identity—namely, theology/religious studies, philosophy, Catholic Studies, and curricular programs focused on justice and peace.

The present situation in Christian theology demands that it be constructed not in isolation but in relation with other religious and theological visions. This is not to insist that Christian theology should surrender all of its claims to better accommodate an emerging melting pot. The objective of pluralism is not lowest common denominator theology Syncretism leaves little reason for adherence to any particular theology. However, it is to suggest that Christian theology must be formulated, now and in the future, with an explicit and sympathetic consideration of its relationship to the other major religions. In the first centuries of the development of Christianity, Christian theology was formulated intentionally to separate itself from other theological and philosophical claims. By distinguishing itself in its theology, Christianity was able to establish itself as an independent

Responsibility for the curriculum resides in the hands of the faculty, many of whom may be more concerned with their discipline than with the Catholic identity of the institution.

and significant force in the religious world. In the present, Christianity must understand itself not in contrast but in relation to other religious possibilities and traditions. Such study takes care and expertise to do thoughtfully and well.

As one example, the theology department at Georgetown University takes its Catholic identity seriously and the identities of other religions as well. The introductory course in theology, a requirement, bears the title The Problem of God, named in recognition of the contributions of the Jesuit theologian and Vatican II Peritus, John Courtney Murray, who published a book of the same name, The Problem of God, in I964 (based on his I962 Thomas Aquinas lectures at Yale University). This course introduces students to the arguments for and against the existence of God and requires them to grapple with the question of God and its implications socially, politically, and personally. The theology department website explains the requirement thus: "Georgetown University, with its commitment to the Jesuit tradition, believes that modern men and women should reflect upon their relationship to the world, their fellow humans, and God." The learning goals of the department, aware of the religious diversity in which we are all embedded, 
talks about religious traditions, not simply one tradition of Catholic Christianity: "The Department of Theology provides students with tools to study the complexity and power of religious traditions. It also assists students with understanding the place of theology and religion in the human enterprise."

In practice, the course has historically relied upon the biblical texts and arguments formulated in the Western theological and philosophical traditions. However, in the past twenty years or so, many professors have introduced texts from other religious traditions that share the same aim. Other religious traditions also struggle with the question of God (or the Transcendent). Students who come from various traditions recognize this reality and appreciate broader theological and philosophical investigation of the issues, and sometimes engage more fully, when professors use texts from multiple religions, not just Christianity or Judaism. This use of texts from multiple traditions has been the result of faculty hiring and religious diversity among the student body. Many recent faculty have degrees in religious studies, which includes exposure to religion widely conceived. They arrive with an understanding of texts and traditions other than Christianity. In the classroom, they encounter students from a range of religions as well as a growing number who identify as what sociologists label as "nones" (no religious affiliation). This is no longer I950s Catholic education, when the majority of students were active Catholics educated in parochial high schools.

On the graduate level, in 2005 the theology department inaugurated a Ph.D. degree focused on religious pluralism. The description of the program states that "being religious today means, even in the United States, being interreligious and calls for intercultural and interreligious understanding and collaboration on both the national and international levels." Students do coursework and take comprehensive exams in two traditions. The program design recognizes and explores multiple religions, preparing scholars that can work across traditions theologically, ethically, and methodologically. It prepares scholars who are conversant with more than one religion for a world, and an academy, that is pluralistic.

Georgetown's commitment to the exploration of, and the conversation between, religions is grounded in the Jesuit and Catholic tradition. It also looks to expand that tradition, to shape it going forward, to lead it in this century. It does so fully cognizant of its commitments, tradition, claim to authenticity, and desire to be faithful. Designed to engage contemporary students in a thoughtful and careful exploration of the self and the other that leads to new insights about both, this theological curriculum requires sophistication and knowledge beyond the scope of Christianity. It prepares students at the undergraduate level and professional scholars on the gradate level to wrestle with the pluralism in which they live. It provides the means to make informed comparisons, to identify genuine differences, and to find common theological and practical ground. Isn't this what a contemporary department of theology should do, without ignoring the solid grounding in tradition in order to do so?

\section{Consistent with the Mission of the Jesuits}

How does this focus on religious pluralism fit with Jesuit principles and directions for the order? The 35th Congregation of the Jesuits confirmed that the mission of the Jesuits involves commitment to dialogue with cultures and religions.

In this global world marked by such profound changes, we now want to deepen our understanding of the call to serve faith, promote justice, and dialogue with culture and other religions in the light of the apostolic mandate to establish right relationships with God, with one another, and with creation. ${ }^{24}$

The clearest evidence for this mandate to dialogue with other religions comes from "Companions in Mission: Pluralism in Action," a speech delivered by Fr. Adolfo Nicolás, S.J., the Superior General of the Society of Jesus, delivered at Loyola Marymount University on February 2, 2009. ${ }^{25}$ He stated:

[T]hroughout Jesuit history, Jesuits also saw themselves as co-workers and companions with non-Christians, with all men and women of good will—men and women with a good heart. ... While Jesuits bring their own distinctively Catholic, Christian identity to whatever work they join, they know that others' projects are not always conceived explicitly in Christian or even religious terms. They join such projects, with the identities that are their own, because they see deep consonance between the non-religious mission and their own criteria for mission. Similarly, they ask members of other-religious traditions or simply men and women of good will to join in their own sponsored works without, in any way, asking of them that they deny or negate their own identities in the common work.

This speech echoed the ideas of the Jesuits' 35th General Congregation, Decree 6 ("Collaboration at the Heart of Mission"), which stated: "We are enriched by members of our own faith, but also by people from other religious traditions, those men and women of good will ... with whom we labor in seeking a more just world." ${ }^{26}$ In its conclusion, GC 35 states: "The Society desires strong relationships in mission with as many collaborators in the Lord's vineyard as possible." ${ }^{27}$

Elsewhere, Fr. Nicolás has noted that "Historically, Jesuits have run schools (for example, in Islamic lands) where they explicitly promised they would not try to convert anyone. They did so because of the work's resonance with their mission goals of helping people, of reaching toward the greater or more universal good, and of cultivating a faith that does justice." Further, "It should not cause surprise that Jesuits, whose originating charism dictates that they attempt to discern and find God present and laboring in all things, might also try to find that same God working in and present to all persons,

24. Society of Jesus, General Congregation (GC) 35, Decree 3, section III.12, online at http://www.jesuit. org/jesuits/wp-content/uploads/GC 35 _web.pdf. (citing the Compendium of the Social Doctrine of the Church, $\ 575)$.

25. http://www.xavier.edu/jesuitresource/online-resources/Addresses-and-Keynotes.cfm

26. GC 35, Decree 6.3.

27. GC 35, Decree 6.24. 
whatever their identities, traditions, cultures or religions." ${ }^{28} \mathrm{He}$ also underscored that the Jesuits have made a firm commitment not only to working with persons of other faiths but also to interreligious dialogue. He wrote:

Others, however, (as experience has shown) can contribute to the mission and dynamic of Jesuit works from their own specific religious identities or on more secular humanistic grounds. They will never be constrained to embrace the Catholic faith or forfeit their own identity. Yet all companions in mission in a Jesuit-sponsored work will recognize that, for their Jesuit colleagues, the main rationale for mission will continue to be deeply rooted in their concern for furthering Jesus' preaching and enactment of the Kingdom of God in its justice and right relationships.

In the document, Fr. General Nicolás underscores that while Jesuit spirituality is Christo-centric, elements of Ignatius's Spiritual Exercises can be fruitfully appropriated by non-Christians.

The most prominent Jesuit, Jorge Bergoglio, before his elevation to the papacy as Pope Francis, had good relations in particular with the Jewish community in Argentina and wrote:

Dialogue comes from an attitude of respect for another person, a belief that the other has something good to say, to make room in our hearts for their point of view, opinion and proposal. Dialogue involves a warm welcome and does not involve dismissing a person offhand. To talk we must know how to lower defenses, open the doors of our houses, and offer human warmth. ${ }^{29}$

Shortly after his election as pope, he sent a message to Rome's Chief Rabbi, Riccardo Di Segni, inviting him to the inauguration Mass and telling him: "I very much hope to be able to contribute to the progress that relations between Jews and Catholics have experienced since the Second Vatican Council, in a spirit of renewed collaboration and at the service of a world that can be ever more harmonious with the will of the Creator." 30

\section{Conclusion}

Clearly, interreligious dialogue and encounter should be part of Jesuit colleges and universities. Georgetown has made welcoming the religiously other a hallmark of the institution. By no means is it the only Jesuit institution of higher learning doing so. All of us who work at Jesuit schools recognize this charism. Highlighting it in this paper underscores its importance for all of us.

Welcoming the religiously other to Jesuit universities and colleges opens doors to

28. Adolfo Nicolás, S.J., "Companions in Mission: Pluralism in Action," Mission Day Keynote Address at Loyola Marymount University, February 2, 2009, online at http://www.udmercy.edu/mission/ Archived\%20Information/Lent\%202009/Nicolas_LMU_09.doc.

29. Jorge Bergoglio and Abraham Skorka, Sobre el Cielo y la Tierra (On Heaven and Earth, Sudamericana, 2011).

30. "Francis Writes Rome's Chief Rabbi," March 14, 2013, at http://www.zenit.org/en/articles/franciswrites-rome-s-chief-rabbi. dialogue, acknowledges a religiously pluralistic society, recognizes that other religions (and their adherents) deserve respect and a voice in the conversation, and proves consist ent with Jesuit teachings and practices. This charism of welcoming the religiously other should not be taken for granted. It can be ignored, downplayed, or forgotten-to the detriment of the institution and its constituents. Or it can be a hallmark of Jesuit higher education in the twenty-first century. We are not trying to convert the other, but first and foremost to understand the other. The dialectic that preserves Jesuit and Catholic identity, while respecting and learning from the other, forges a relationship that benefits both parties without disenfranchising either. Jesuit universities do not seek to become Muslim, or Jewish, or Hindu. They do, however, seek to welcome Muslims, Jews, and Hindus. In an increasingly pluralistic world, this charism underscores engagement with the world, a quality of Ignatian spirituality and Jesuit practice for more than four hun dred and fifty years.

The student tour guides who introduce visitors and prospective students to Georgetown on campus tours are often asked about the role of religion, religious belief, and practice at Georgetown. Some enquirers fear proselytization in the classroom and the campus by Catholics who want to make others like them. Some worry that Georgetown has lost its Catholic footing. Others want to know that their faith commitments will be honored and respected. The tour guides answer that at Georgetown you do not have to leave your religion at the gate. They do not specify what religion. All are welcome.

If we welcome religiously diverse students to our campuses, then, are we not obligated to accommodate them? That means serving their religious needs as well as their academic requirements, whether they are Catholics, Protestants, Jews, Mormons, Hindus, Buddhists, or Muslims. We do this while not surrendering our central identity, Catholicism. We do it with respect and sensitivity. We do it out of conviction that the "religiously other" is still a college student, our college student.

This charism of welcoming the religiously other benefits all of our students, as they encounter a diverse culture that mirrors the world outside of the university walls. Here, they learn about each other's religion, they encounter difference, and they appreciate the uniqueness of their own tradition while seeing its similarities with the traditions of others. Is this not good preparation for life after college? Many meet their life's partner while in college. Some of these unions will be interfaith. Providing a deeper knowledge of religious traditions prepares them for the increasingly diverse world they will work in, raise their families in, and practice their professions.

I conclude with a quotation from Introduction to the Study of Religion, an influential book used in religious studies courses written by five members of the Department of Religious Studies at a Jesuit institution, LeMoyne College. It captures well the spirit of dialogue all of us should embrace, promote, and practice.

While cultures develop their own characteristic ways of understanding the human condition, modern circumstances bring people from different cultural backgrounds together within the same nation and even within the same 
city. Hence, people may be, at one time, exposed to several worldviews, each employing its own metaphors, each proposing a model for understanding the human condition. ... . Such multicultural situations call for respect, and they afford opportunities to stretch our imaginations as, along with our fellow human beings of various cultural backgrounds, we try to comprehend and negotiate our time and place in the world. In order to reflect on religion in multicultural contexts, openness and willingness to dialogue are essential. ${ }^{3}$ 